\title{
NEW MEDIA TECHNOLOGY IN DEVELOPING EFFECTIVE ORGANIZATIONAL INTERNAL COMMUNICATION
}

\author{
Nur Kholisoh $^{1}$; Ria Sulastri ${ }^{2}$ \\ ${ }^{1,2}$ Master of Communication Science, Post Graduate Program, University of Mercu Buana \\ Jln. Meruya Selatan No. 1, Kembangan, DKI Jakarta11650, Indonesia \\ 1'nur.kholisoh@mercubuana.ac.id/kholisoh.nur@gmail.com; ${ }^{2}$ riasulastri@mercubuana.ac.id
}

\begin{abstract}
The article was intended to investigate various benefits of Whatsapp Messenger application for an effective intenal communication in PT Euro Management Indonesia. In addition, this research also aimed to map the organizational internal communication pattern through the use of Whatsapp Messenger application. The research used theories of organizaional communication, new media communication pattern, and computer mediated communication (CMC). Moreover, paradigm used in the research was constructivist with qualitative approach and the research method was case study. The research result finds that the use of new media Whatsapp Messenger as a tool of communication can build effective internal communication in PT Euro Management Indonesia. Moreover, it also shows that the internal organizational communication pattern in PT Euro Management Indonesia used in Whatsapp Messenger application is conversation pattern.
\end{abstract}

Keywords: new media technology, Whatsapp Messenger, effective commucation, communication pattern

\section{INTRODUCTION}

Effective communication occurs when individual reaches mutual understanding, stimulates others to act, and pushes others to think in a new way. Effective communication skills will increase productivity either in the level of individual or organization, so the skills allow the individuals in the organization to anticipate problems, make effective decision, coordinate workflow, supervise others, develop relationship, and also promote working programs and organizational services.

However, it is considered that communication process is not always effective since there may be some barriers that can inhibit effective communication, such as distance and structure factors. Those communicaton barriers also occur in the internal communication of PT Euro Management Indonesia as a professional institution whose core business is to provide integrated international education consultation and services for Indonesian student candidates who are willing to continue their studies to universities in the European countries.

Poor communication among employees in obtaining and enhancing their working performance can potentially cause negative impact to the company's ineffective performance level. The poor communication seems to result in bad relationship among employees, authoritarian or indifferent attitude, and the prolonged debate or conflict, from which can bring about undesirable work results. It occurs that the disseminated information only works well in the level of managing director and directors. Consequently, there is more particularly uneven information dissemination for the employees. 
In the information dissemination, the managing director makes coordination to the company's directors, and then he/she will disseminate the information to their subordinates. In this level, sometimes the information is not disseminated equally. In the next level, the managing director still holds a general meeting for all employees and reviews all previous information having been disseminated to determine that the information is really disseminated to all employees equally. It definitely requires face to face sessions where the managing director can deliver the information once again. Moreover, he or she should gather all employees in effective hours.

With the intention to overcome the problem, PT Euro Management Indonesia makes use of media as a tool of communication, which is called Whatsapp Messenger or Whatsapp, in short. Whatsapp has been one of the most popular mobile phone messenger applications in Indonesia from the time it was officialy released until present days. It is considered to be a very supportive messenger application on mobile phone where its users are able to instantly send message to each other. Whatsapp application enables people using it to interact easily and effortlessly as if they are in the same area, standing face to face, and talking to each other. Whatsapp has just launched its newest feature called Broadcast Message. This broadcast feature enables users to communicate and disseminate information not only to one single user, but also many other users. Moreover, PT Euro Management Indonesia uses it to overcome communication barriers in internal organization. Whatsapp group chat is used as the internal communication media to carry out coordination, socialization, decision making, voting, and other internal interaction in PT Euro Management Indonesia.

Based on the aforementioned phenomenon, there are two research problem that is going to be discussed, which are: (1) how do the patterns of internal organizational communication develop the effectiveness of corporate communication by using Whatsapp for the employees of PT Euro Management Indonesia? (2) How does the new media utilization of Whatsapp by PT Euro Management Indonesia develop the effectiveness of internal organizational communication? The objectives of this research are: (1) to map the patterns of internal organizational communication in developing the effectiveness of corporate communication by using Whatsapp application for the employees of PT Euro Management Indonesia, and (2) to investigate the new media utilization of Whatsappin PT Euro Management Indonesia in developing the effectiveness of internal organizational communicaiton.

The research is expected to increase and expand research knowledge, particularly in communication science, i.e. new media study in organizational communication. It is also expected to become reference and research source for other researchers, so the application can be interpreted in the social interaction of communication or they will do subsequent research. Besides, it is considered that this research can practically give contribution, particularly for practitioners and organizational behavior in communication patterns and procedures as effective and efficient as possible. For public, the research is not only expected to have benefits to the related parties but also to enable public to know benefits of Whatsapp application.

There are two previous researches discussing new media and its relationship to organization or institution. The research result finds that the use of Whatsapp among students has negative impact to their academic performance. It occurs the time wasted for them using cellular phone is more than eight hours per day, and it reduces learning hours. Moreover, students have less concentration in learning process (Yeboah and Ewur, 2014). It also finds that there are many grammar errors in students' writings. The difference between the research by JohnsonYeboh and George Dominic Ewur and this research lies in the research objective and type. This research uses qualitative approch with the purpose of knowing communication pattern and benefits of using Whatsapp application in corporate internal communication. 
The second one is a research conducted by Rousseau and Puttaraju (2014) from Department of Communication, Bangalore University. The research sees the improvement of using one of the most popular social media, Facebook, in the working environment of Public Relations (PR). The research result indicates that PR professional uses Facebook to get journalists' contact number, to create journalists' chain, and to use Facebook as tool of providing information from different perspectives. They use case study method with the data-collecting technique of in-depth interview. It is similar to the research method used in this research. Another similarity between the two researches can be seen from the research objective, which is to know the benefits of social media uses. The research carried out by Jesus et all sees social media uses of SNS (Social Networking Sites) refers to the website Facebook, and this research refers to media social application of instant messaging, Whatsapp.

In the organization process, communication has important role to the achievement of organizational goals. Goldhaber (Muhammad, 2009) has defined organizational communication as a message exchange process in a network of interdependent relationships. It can include an open system which gets influence from internal or external environment, or message, flow, attitude, feeling, relationship, or the members' skill in the organization. According to Weick, as cited by Littlejohn (2014), organizations are not structures made of positions and roles, but communication activities. It is more appropriate to speak of "organizing" than of "organization" because organizations are something that people accomplish through a continuous process of communication.

If communication reaches its target, the company can use appropriate communication methods. According to Effendy (2006), it should be considered as well that communication in organization can be grouped into two forms of communication, i.e. internal and external communication. Lawrence D. Brennnun (Effendy, 2006) has stated that the internal communication is defined as the exchange of ideas among administrators and employees in a company or institution plus with its unique structure (Organization) and the exchange of ideas in horizontal and vertical way in the company or institution. Therefore it causes the on going job activities (Operation and Management).

Human being's communication way changes from time to time after new media appears. Inter-individual relationship does not only occur in face to face meeting but also it gets mediation through technology devices. The advent of the Internet has changed a way of communication in the level of interpersonal, group, organization, and inter-culture. Holmes (2005) has stated that the Internet is the milestone of global interaction technology in the end of 20th century. It changes the scope and basis of communication medium. The transformation is called second media age where traditional media from radio, newspaper to television have been left behind among audience. Basically the traditional media uses information dissemination pattern from one source to audience in great number, one-way form and minimal in number as well as no sender-receiver interaction.

With the statement 'medium is the message', McLuhan, as cited by McQuail (2011) has pointed out that social consequence from the advent of new media in the development of social life pattern includes communication patterns. New media theories state that a revolution of replacement occurs from broadcast pattern to network. The Internet becomes alternative media from the old pattern, which is broadcast pattern. Communication patterns through new media differ from the traditional ones.

The advent of new media gives opportunity to the establishment of new patterns in communication process. The communication patterns are the forms of communication to influence through signal or symbol in a kind of sending one and invite gradually or instantly. McQuail (2011) has explained that a new pattern of information flow has been developed by two Dutch telecommunication scientists; J.L. Bordewijk and B. van Kaam. They described four basic patterns of communication and they appointed how the patterns have inter-relations: (1) allocution, the pattern which occurs when information flows from one source; (2) conversation, the pattern which occurs when there is information exchange between two persons or more; (3) consultation, the pattern in 
which audience or person wants to look for information from one similar source; and (4) registration, in which the patterns occurs when the center of information receives information from audience, and it collects it.

Nowadays, communication sector develops quickly in the advent of various new technologies, which provide facility to the users. Computer as software microchip technology has carried out information process that human beings may integrate into their daily life activities. In social life, the computer provides new experience for human beings. That statement is based on the fact that computer was difficult to buy due to its expensive price. Nevertheless, computers these days vary in brands, qualities, and prices so that people can choose the ones they need and use the computers to support their daily life activities. Meanwhile, according to Griffin (2012), media enables human beings to mix and match various kinds of life styles and tastes to create a unique identity.

According to Morreale et al. (2007), Computer Mediated Communication (CMC) is an interhuman being interaction through computer technology that has inter-connection to the multi-purpose media formation. Mediated communication is a form of communication which applies any kind of media to send message either through paper or letter, and CMC is able to send message through digital-device computer media such as mobile phone and computer. The differences only relate to the media uses. Through CMC, a person can submit his or her feeling but he or she is not able to see the response, feedback, and body language from the message receivers. Some inter-related factors in CMC (Morreale et al., 2007) are (1) individual factor which includes technology knowledge, skill, and motivation; (2) CMC factor which consists of completeness and openness; and (3) message factor which covers ambiguity, complexity, and emotionality.

The use of Whatsapp application in communication activity can be categorized into the CMC theories because Whatsapp is an application on mobile phone or smartphone that used as the media of Computer Mediated Communication (CMC). For the advantages, Whatsapp uses the 24-hour Internet connection, and therefore someone is able to send and receive any messages everytime and every where. Whatsapp users are able to exchange image, audio, or video. Moreover, they can make online chatting group via Whatsapp consisting of many users to be the members of the group.

\section{METHODS}

The object of research is PT Euro Management Indonesia since this company use Whatsapp application as the pattern of internal organizational communication to build corporate communication effectiveness.

The paradigm used in the research is constructivism because the reseachers consider that there is a phenomenon established from social interaction. It is viewed that the reality is actual. However, the reality is multiple, where its meaning differs from one person to another. Moreover, there is social interaction development toward the rapid development of media technology in the construction or change of communication pattern in organization through the use of Whatsapp application.

The research uses case study method. Through the qualitative approach, the researchers are encouraged to investigate more deeply about the organizational internal communication pattern through Whatsapp application among employees of PT Euro Management Indonesia.

The primary data used in the research comes from the results of in-depth interview with informants and structured interview. The secondary data is collected through literature study and data 
observation. In this matter, the researchers conduct data collection and data analysis to the research from communication on Whatsapp application.

The informants in the research are considered to be competent since they have been working at the company for quite a long time, so they have had many experiences regarding the information dissemination activities. They are also actively involved in the environment and activities as the focus of the researchers. Moreover, they are ready to give information due to their objective attitude with no prior preparation. More importantly, these informants are the ones who have enough time to give any information required for this research. Based on the criteria, as informants in the research, the sources are Director of PT Euro Management Indonesia, Head of Human Resource Development (HRD) of PT Euro Management Indonesia as well as administrative staff, and the other employees who become the members of Whatsapp group of PT Euro Management Indonesia.

The data analysis in the research includes: (1) data reduction which covers selection, focusing, simplification and abstraction of data from field note, (2) data presentation which includes the arrangement of information organization, description in a form narration so that the conclusion can be drawn, and (3) conclusion drafting and verification in which the final conclusion will not occur until the data collection process comes to an end.

The research does data validation test in a form of data triangulation, i.e. data checking from various sources in many ways and times. The data triangulation in the research is conducted by comparising the main informants' answers to the supporting informants' to get adequate and appropriate data, i.e. data taken from in-depth interview and examined through observation and documentation.

\section{RESULTS AND DISCUSSIONS}

PT Euro Management Indonesia uses face to face communication as a way of internal communication, and it also applies phone call and text message in the organizational internal communication. PT Euro Management Indonesia has used Whatsapp since 2014 because it is considered suitable for the communication in the company, i.e. the coordination of information dissemination. Moreover, Whatsapp can load many members into the group, have greater resolution to send data, photos and videos. Importantly, the company's employees have been more familiar with using Whatsapp than other instant messenger application.

Based on the results of in-depth interview, it is found that each Whatsapp group is made on the basis of problems or activities, which means that each update should be informed to the superiors and all employees as well. Moreover, it has been the company's unwritten regulations that CEO, directors and superior have active role as the admins of the group, so they become the responsible parties to all information submitted into any Whatsapp groups. Moreover, they are considered as people having the authorities to add or even discharge the member(s) of the groups.

The purpose of using Whatsapp application among employees of PT Euro Management Indonesia is to make coordination and information dissemination easy to all the company's employees. In general, Whatsapp groups in PT Euro Management Indonesia are created based on information types. From the research results, the information of Whatsapp groups of the company is divided into: (1) Whatsapp group for inter-department information request; (2) Whatsapp group which is intended to disseminate information to all employees; and (3) Whatsapp group for internal department coordination. 
The disseminated information in each Whatsapp group will be stated again by each head of departments in the company's Board of Directors. Moreover, all issues are discussed in the meeting. The meeting results will be submitted again by heads of departement to each department staffs, so the information is delivered to all staffs. Concerning the flow of communication from superior to subordinate, Chiefs of PT Euro Management Indonesia will do direct communication or give direction or instruction via Whatsapp groups. The direction or instruction stated by the company's superior will be directly responded by the subordinates, in this case, employees. On the other hand, the form of communication from subordinates to superiors will be delivered in a form of reports via Whatsapp application. Based on the research results, interaction or two-way communication between the company's superiors and subordinates will appear if there are some problems found in the reports. Moreover, the company's superior will do direct response particularly from the company's CEO and President Director. From the results of in-depth interview with the source, it can be concluded that the form of communication to the company's superiorsis report via Whatsapp groups. The interactive communication will occur if the company's superiors repond to Whatsapp groups.

Horizontal and diagonal communications via Whatsapp support the interdepartmental communication, which is communication among employees. There are so many communication activities via Whatsapp groups for some coordination from one employee to other employees. It becomes two-way or feedback communication, in which one employee gives response to other employees' information. The members of Whatsapp groups consist of CEO, Board of Directors, managers and employees from various departments in PT Euro Management Indonesia.

Whatsapp groups in PT Euro Management Indonesia turn out to provide some benefits. Firstly, it becomes a tool of management control in a form of subordinate's reports. Secondly, the organizational internal communication via Whatsapp application is far more effective for communication and anticipation from important disseminated information since the cost is considered more affordable than text message and phone call. Thirdly, it does not have distance and time barriers so that every user involved in Whatsapp groups can communicate at any place and time. Fourthly, all informations are saved in Whatsapp groups as well as some track records in each data in the group. Finally, sending images, documents in pdf files, and videos for report activities among employees turn out to be really easy, effortless, and fast.

The use of Whatsapp application in PT Euro Management Indonesia is fast, affordable in cost and great in number of group members. When observing the organizational internal communication patterns of PT Euro Management Indonesia, the researchers divide them into three parts, i.e. (1) vertical communication, (2) horizontal communication, and (3) crosswise communication.

In the company's upward communication process-from subordinates to superiorssubordinate gives reports, information, ideas, targets and others to managers or superior via Whatsapp application. For example, Whatsapp proceedings and action plan in each department have function of reporting all progress in the department. Since there are many Whatsapp groups, the employees of the company only report problems and progresses occurring in the company into the Whatsapp groups regularly. Nevertheless, there is rarely any responds, feedbacks or interactions regarding the reports. From the flow of information, the communication pattern to the company's superior is allocation, that is the communication pattern in which information flows from one source without any feedback despite the great number of employees receiving the messages.

In the company's downward communication - from superiors to subordinates - the management of PT Euro Management Indonesia gives instruction, direction, guidance, explanatory information and others to its subordinate via Whatsapp group. Based on the research results, the company's employees will give response to the superior's instruction out of office hours directly. Therefore, responses, feedbacks, and interactions happen in the flow of this downward communication. 
Moreover, horizontal communication in Whatsapp groups of PT Euro Management Indonesia has the function of coordination among employees. When there are many coordination activities via Whatsapp groups, these change into the pattern of conversation. The Computer-Mediated Communication (CMC) has two characteristics. First, CMC is said to be interactive. It means that the system or program is capable of asking something to the users (in the question-answer format), and making decision based on users' response. The second characteristic of CMC is synchronicity, which means that Internet communication occurs in a kind of immediate interaction. It uses words as the message being sent and received immediately similar to a direct conversation in daily activities.

The Crosswise Communication via Whatsapp in PT Euro Management Indonesia interdepartmental groups in which all employees are invited as the group members, i.e. Whatsapp group GA-Transportasi and ACD-Marketing Request. Whatsapp group of GA-Transportasi has a function of keeping an eye on where the company's cars go. Besides, it is also possible for the company's employees to make request for the company's transportation facility, in this case, cars. Moreover, Whatsapp group of ACD-Marketing Request has a function for the company's marketing department staff to have requests or questions to the group members and even to other chiefs of department. Main communication objective is to give direct channel of organizational coordination in the problem solving process. It is carried out to avoid any slow-track procedure in the direct coordination to the superior's order.

The use Whatsapp allows the company's employees to get information access in a form of text and image via Whatsapp group in the academic group. Therefore, the corporate communication can go effectively. The objective of Whatsapp use in each department of PT Euro Management Indonesia is reachable, i.e. even information dissemination process to all employees becomes effortless and comfortable.

Krech, Cruthfield, and Ballachey in Sudarwan (2004) formulated a theory that the scale of effectiveness in a group depends on some points, and it can be seen in corporate internal communication effectiveness in PT Euro Management Indonesia as well. Firstly, it relates to the group scale. Based on the research results, there are some uses of Whatsapp application in PT Euro Management Indonesia. The company classifies the Whatsapp groups into each function and use. The Whatsapp group of ACD-Visa has a function of informing the progress report of students' visa who will depart. The group's admins involve CEO, Board of Directors, and chiefs of department. Admins function as the ones who invite or add members to and discharge members from the group members. Hence, the company's superiors have an obligation to hold admins' position because they understand really well about the employees that are going to be added or invited to the Whatsapp group ACDVisa. Not all employees can join the group. Department employees with the job description of visa process are the ones able to join, such as the academic staffs of Germany-based graduate program. The total number of staffs joing is three. The procedure makes the reporting and communication in the Whatsapp group more effective.

Secondly, it relates to the line of communication. Based on the research results, the flow of information via Whatsapp Academic Department enables the company's Board of Directors and Head of Division to easily access to the disseminated information in the group. All important information in Whatsapp group is presented again and submitted by the company's superiors to all subordinates, in this case, employees. Moreover, the company creates Whatsapp group of HRD-News \& Info, which functions to sumarize all important activities in the company including those in the company's level of departments. 


\section{CONCLUSIONS}

This final chapter contains several conclusions from the entire analysis. When PT Euro Management Indonesia builds effective communication, it is found that the communication patterns in the organizational internal communication of PT Euro Management Indonesia use three conversation pattern, which are: (1) vertical communication which is communication to the company's superior and to subordinate, (2) horizontal communication and (3) crosswise communication. The conversation pattern indicates some balanced interaction in information dissemination and gives the opportunity of feedback process. Moreover, for the communication to the company's superior, it also uses allocation pattern in which the company's employees provide regular daily report on the Whatsapp group. However, it does not occur in a kind of feedback. It also occurs to the diagonal communication, which uses two communication patterns, i.e. the conversation and the consultation pattern for which the company's employees ask information in the Whatsapp group.

The use of Whatsapp application in organizational internal communication of PT Euro Management Indonesia results in various benefits that build effective communication. All employees from superior to subordinate can communicate more effectively, and even carry out disseminated information. Therefore, the company's organizational employees know all corporate activities and they will minimize misunderstanding. Finally, the company is able to make its own documentation on the information and data of the corporate activities saved in the Whatsapp application.

Considering that there are many more Whatsapp groups made by PT Euro Management Indonesia, it is possible that they will trigger misunderstanding among the company's employees in the information dissemination. Therefore, PT Euro Management Indonesia has to classify which Whatsapp groups considered to be important. Therefore, all superiors are able to control all Whatsapp groups.

\section{REFERENCES}

Effendy, O. U. (2006). Ilmu Komunikasi Teori dan Praktek. Bandung: PT. Remaja Rosdakarya.

Griffin, E. (2012). A First Look at Communication Theory ( ${ }^{\text {th }}$ Ed.). USA: McGraw Hill Higher Education.

Holmes, D. (2005). Communication Theory: Media, Technology, and Society. London: Sage Publications.

Littlejohn, S. W., \& Foss, K. A. (2014). Theories of Human Communication $\left(9^{\text {th }}\right.$ Ed.).Translator by M. Yusuf Hamdan, Jakarta: Salemba Humanika.

McQuail, D. (2011). Teori Komunikasi Massa McQuail. Translated by Putri Iva Izzati. Jakarta: Penerbit Salemba Humanika.

Morreale, S. P., Spitzberg, B. H., \& Barge, J. K. (2007). Human Communication ( $2^{\text {nd }}$ Ed.) California: Thomson Wadsworth.

Muhammad, A. (2009). Komunikasi Organisasi. Jakarta: PT Bumi Aksara. 
Rousseau, J. M., \& Puttaraju, K. (2014). SNSs \& PR Professionals: A Case Study of Facebook PR Groups as a Tool for Building Media Rapport. International Journal of Humanities and Social Science Invention, 3(10), 2319-7722.

Sudarwan, D. (2004). Motivasi Kepemimpinan dan Efektivitas Kelompok. Jakarta: Penerbit Rineka Cipta.

Yeboah, J., \& Ewur, G. D. (2014). The Impact of Whatsapp Messenger Usage on Students Performance in Tertiary Institutions in Ghana. Journal of Education and Practice, 5(6), 157164. 